\title{
Payment Delays and Financial Performance of Construction Firms in Vihiga County, Kenya
}

\author{
Brenda Ajema Kalegera ${ }^{1} \&$ Nixon Oluoch Omoro ${ }^{2}$ \\ ${ }^{1}$ School of Business University of Nairobi, Kenya \\ Correspondence: Nixon Oluoch Omoro, School of Business University of Nairobi, Kenya.
}

Received: January 21, 2020

doi:10.11114/aef.v7i3.4775
Accepted: February 24, $2020 \quad$ Available online: March 18, 2020

URL: https://doi.org/10.11114/aef.v7i3.4775

\begin{abstract}
The purpose of this study was to establish whether payment delays affect financial performance of construction firms. The study employed cross sectional research design, stratified simple random sampling and census survey of 32 construction firms. The study relied on secondary data from audited financial reports. Data was analyzed using both descriptive and inferential statistics - multivariate analysis. There was no statistical significant effect between delayed payments and financial performance as measured by Net profit margin and current ratio, probably other factors or measures such as management style and strategies could have affected the two variables. Our conclusion however, is that late payments in commercial transactions by the public or generations and private entities have detrimental effects on the business environment, especially by exacerbating the burden of already financially constrained firms which can ultimately push them out of business. The study was only limited to one financial year and construction firm.
\end{abstract}

Keywords: payment delays, net profit margin, current ratio, construction firms

\section{Introduction}

\subsection{The Study Problem}

Payment Delays result into deterioration of firms' financial performance. Efficient and timely payments to organizations is a significant factor leading to enhanced financial performance since the cash flow position of an organization determines its success or failure (Jiang, 2010;Hasmori, Ismail and Said 2012). Delayed payment can threaten the survival of any organization as it becomes difficult to budget without a clear cash flow projection, hence distorting all financial plans and expected revenue flow, suggesting that firms find it difficult to break even, eventually resulting into liquidation (Hamid, Zakaria, Badroldin, Raman and Mohandes, 2016). It is important that firms closely observe and manage their receivables since prolonged payment delays create more cash flow problems that results into delays in completing projects (Abdul-Rahman, 2009).Cash flow is therefore the primary indicator of a business financial health (Nasser, 2013). Payment delays should be prudently managed by firms since Arrears are found to weaken private sector activity and undermine financial stability. Importantly, arrears reduce the ability of fiscal policy to support the economy, by reducing (even turning negative under some circumstances) the multiplier effect of government spending (Diamond and Schiller 1993).

\subsection{Why Payment Delays}

Wuni, Boafo and Kumi (2017) refer to payment delays as honouring payments at a later time other than the stipulated contract period. Diamond and Schiller (1993) defined payment delays as the difference between obligations due to suppliers and the government's ability to discharge these obligations in a timely fashion in a given financial year. Flynn and Pessoa (2014) defined payment delays from a public context as government liabilities accrued from goods, services and fixed assets supplied by suppliers. The concept is well though as is an important concept in financial management and reporting. A late payment delay generally occurs when the collection period exceeds the credit period granted to customers. We anchored the study on agency theory by Jensen and Meckling(1976) and Wreckers' theory of financial distress by Campbell, Hilscher and Szilagyi (2006).The agency theory postulates how the project owner, as the principal, relates with the Contractor, as the agent being contracted in a specified contract, by delegating services to him, so as to construct infrastructural facilities on his behalf (Ceric, 2012; Eisenhardt, 1989). This theory seeks to address the conflict that might arise from the payment delays and how it might affect the contractors financial position. On the other hand, Wreckers' theory of financial distress advances that, benefits that may arise out of financial distress to stakeholders do not 
necessarily attribute negative surplus returns of distressed firms, especially to firms which are less efficient. This theory attributes to the fact that payment delays under ideal conditions might result into financial distress, nevertheless, does not necessarily affect all stakeholders negatively, as some of them may benefit during times of bankruptcy proceedings (Kalckreuth, 2005). However, it is important to note that when describing the issue of late payments, the difference between two related concepts need to be taken into account: payment duration and payment delay. The former refers to the effective actual duration in payment incurred by the different public and private agents; the latter refers to the delay which is obtained as the difference between duration and the agreed contractual terms (Connell 2014).

The construction firms contribute to a wider spectrum of the country's economy by providing a multiplier effect to other industries through infrastructural activities and facilities. However, in as much as there are derived benefits from this construction firms, there are inherent problems which have been experienced by this firms such as payment delays. Although infrastructural spending has been increasing in the country over the years, inefficiencies as exhibited in project assessment, choosing, execution, procurement evaluation and matters pertaining to purchasing land in public investments restricted productivity gains from the development spending which in turn increased capital expenditures which were reportedly to have narrowed the fiscal space (Kenya Economic Update, 2017).Most of the construction firms in Vihiga County have been forced out of business as others have become bankrupt, whereas others have had their properties auctioned by financiers, and worst of it, being that some firms have lost subsequent contracts from Vihiga clients due to non-performance, as a consequence of the delayed payment of their invoices (Auditor General's Special Report on Pending Bills of the County Government of Vihiga,2019).pending bills pose as the greatest economic policy challenge in Vihiga County, especially to suppliers and contractors, which is a potentially critical factor behind struggling SME's, many of which seek credit facilities to finance and expand their business operations (Vihiga County Fiscal Strategy Paper 2019).

Flynn and Pessoa (2014) opined that payments delays could arise out of a particular legal obligation or a specific contractual commitment to pay, whereas arrears are subsets of payables that remain unsettled past a clearly defined cut-off date for payment. Delays are experienced basing on the time frame, since various project contracts usually have different time schedules.

\subsection{The Value of the Study}

Delays in payments in business to business and government to business transactions generally have an adverse effect on the cash-flow of firm and can cause firms, particularly small ones, to seek extensions of their overdraft facilities and increase their borrowing (Connell 2014). Payment delays by a single party may impact on the entire supply chain of payment of another party and hence creates cash flow problems (Kwame 2011; Lip, 2003). Delayed payment issues usually become problematic to handle as there is no straightforward statistics on the effect of payment delays on economic performance of a business (Cramer, 1972). Nonetheless, prompt payment is the engine behind superior financial performance of any firm. However, scholars are still divided as to whether delayed payment significantly and negatively affects financial performance (Kwame, 2011; Checherita et.al. 2015; Flynn and Pessoa, 2014). And on that note, the current study provides a spring board on the significance of trade creditor as a major source of short-term financing practices among firm in Kenya. However, much has not been done on construction firms in Kenya due to lack of available and reliable data. The results of the study have greater implications on theory building, policy makers and management practice in terms of business processes and efficient operations in financing business activities.

\section{Payment Delays and Financial Performance}

There are mixed results from extant literature on delayed payments. A longitudinal study by Checherita, et.al, (2015) found out that payment delays to private sector by the government led to a greater likelihood of bankruptcy and declined profits. Another study conducted by Abdul-Rahman (2009) on cash flow management with respect to project delays, found out that the major factor that contributed significantly to delayed project was difficulties in managing cash flow, coupled with inadequate resources, late payment, and the instability of the financial markets, caused majorly by client's inability to manage finances as well as the entire business, similarly, the clients strained while struggling to acquire loans from financiers, altogether combined with the contractors instable financial background, all which contributed to delays. Aibunu and Jagboro (2002) found out that the effects of construction delays on project delivery ranged from constant disagreement, adjudication, total project desertion, prevailing law suits to time and budget overruns. A survey by Mezher and Tawil (1998) established that owners had serious financial issues which in turn impacted on project delay. Similarly, a survey by Assaf and Al-Hejji (2005) established that delay in paying contractors followed by severe cash problems during the construction process caused delays in large construction projects. Another Survey conducted by Mansfield (1994) sought to establish what caused delays in projects under construction and found out that failure by the client to finance and pay basing on completed works, as well as inability to manage the contract efficiently, constantly changing site conditions, inadequate site materials as well as inappropriate planning caused delays. In the same vein, Obodoh and Obodoh (2016) studied project delay causes and reviewed also the resultant 
effects and found out that contractors were faced with problems of deriving interim payments, hence resulting into financial difficulties which when summed up alongside other factors impacted greatly on project delays. On the same breadth, Odenigbo (2018) by using descriptive cross sectional study, sought to establish what caused delayed payments and the resultant effects thereof and found out that constant disagreements on valuation of works together with poor quality of works caused payment delays, whereas payment delays therefore resulted into delayed project progress in instances where project time was extended, ultimately leading to suspended works. Achode and Rotich (2016) conducted as study to assess the effects of accounts payable on financial performance of publicly listed manufacturing companies at NSE, Kenya. The results from this research suggested that in most of the manufacturing firms listed at the NSE, there was a direct positive relationship between Accounts Payable and the dependent variable, Profitability and Liquidity, supporting the Pecking Order Theory. Similarly, a survey by Kwame (2011) found out that delay in payment created stress to contractors, which eventually lead to conflicts, hence creating cash flow problems on all parties to the contract. A causal comparative design study by Okeyo et al (2015) found out that delayed payment to the contractors resulted into ripple effects downward the contractual hierarchy, ultimately impacting on the completion of the projects within the set time, budget and quality as a consequence of contractors' constrained cash flow. A cross sectional study by Akisinku and Ajayi (2016) delineated main causes of delayed payment to contactors on construction project delivery to be unrealistic cash flows, errors in claims, financial difficulties and dispute on valuation of works . On the same breadth, a survey by Seboru (2015) established causes of project delays to be influenced majorly by the clients' payment delays, followed by slow decision making, bureaucracy, amongst other causes which also amounted to delays. A descriptive survey by Akali and Sakaja (2018) found out that contractor's capacity to complete projects was dependent upon a strong financial performance as indicated by profits. A study by Halim et.al (2014) analyzed financial performance and found out that shortage of capital to finance projects, small profits, and higher debt as well as reduced efficiency in asset management contributed to poor financial performance. A longitudinal study by Bhunia.et.al (2011) assessed the financial performance analysis using ratios of profitability, solvency, and efficiency, liquidity, operating efficiency and financial stability and found out that ratios provided the best financial performance measures. Woldesenebt (2011) similarly carried out comparative studies on financial performance of banks using profitability, liquidity, and solvency and efficiency ratios. An ex post facto study by Nwakaego and Ikechukwu (2016) revealed that there was no effect of accounts payables ratios on profitability.

A study by Checherita et al (2015) on the payment discipline of governments to private sector, found out that payment delays led to a greater likelihood of bankruptcy, liquidity problems and declined profits. Abdul-Rahman (2009) reviewed financial related causes from the project delivery perspective, while Seboru (2015) reviewed the factors causing delays but from project delivery dimension, whereas other studies, embarked on causes and effects of delayed payments ( Odenigbo, 2018; Obodoh and Obodoh, 2016; Okeyo et al ,2015; Kwame, 2011; Assaf and Al-Hejji, 2005; Aibunu and Jagboro 2002; Mezher and Tawil 1998; Mansfield, 1994), with some studies in Kenya zero-in to road contractors (Akali and Sakaja, 2018; Mwangi, 2016; Seboru, 2015) whereas other studies focussed only on financial performance (Bhunia.et. al 2016; Muna, 2015; Halim.et. al 2014; Woldesenebt, 2011).With some studies relating accounts payables and financial performance(Nwakaego and Ikechukwu,2016).Some studies corroborated data analysis techniques such as Bayesian vector Auto Regression (Checherita.et.al 2015), whereas others used Relative Importance Indices (Akisinku and Ajayi, 2016).Many studies had been carried out on payment delays to construction firms globally for instance in different states for instance in Nigeria, Ghana, Malaysia, Lebanon, Saudi Arabia and many other states. It is paramount to note that the performances of many firms doing businesses with the government are in tribulations since Part of the problem is that many businesses aren't aware of the consequences of not paying a supplier on time. Specifically for small companies that don't have the luxury of being able to absorb these costs, the fallout is quite devastating. Late payments can have significant impacts on smaller businesses, as their cash flow does not allow them to carry out business as usual without a steady flow of funds coming in (Miller and Wongsaroj 2017). However, in the contrary (Miad and Smith1992) find size, concentration, and credit standing of the firm's traded debt is important in explaining the use of factoring, accounts receivable secured debt, captive finance subsidiaries, and general corporate credit.

\subsection{Conceptual Framework}

This conceptual framework describes the diagrammatic representation that visualizes how variables interrelate with each other. The independent variable being the payment delays is indicated by payment arrears. The dependent variable of the study being financial performance is indicated by Profitability (Net Profit Margin) and Liquidity (Current ratio). Thus, figure 2.1 shows the conceptual model of the relationship between payment delays and financial performance of construction firms in Vihiga County, based on the premise that any change in the independent variable will result in the change in the dependent variable (Kothari, 2004).

Figure 2.1. Conceptual Model showing relationship between Payment Delays and Financial performance. 
Independent Variable Dependent Variable

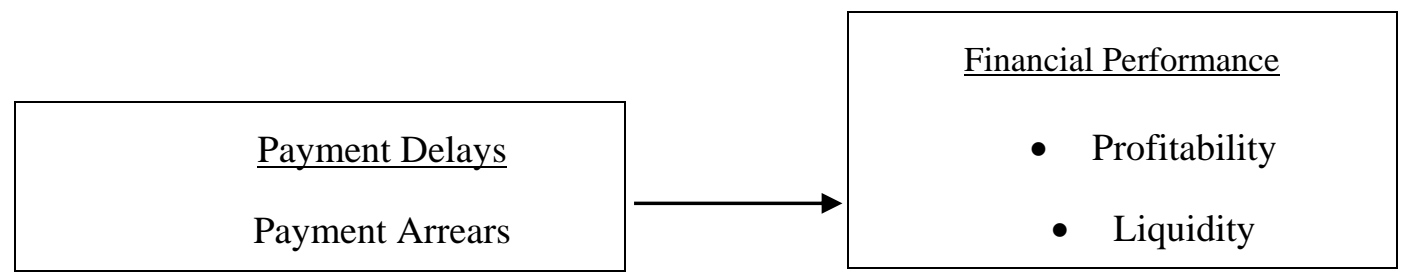

Figure 2.1. Conceptual Model

Source: (Researchers, 2019)

\section{Methods}

The study adopted cross sectional research design and stratified simple random sampling. The stratified simple random sampling was employed on the sampling frame of 40construction firms except for the Installation and maintenance of street light services where census survey was employed. The study used SPSS version 25, where descriptive statistics measures such as mean, standard deviation (SD), minimum and maximum were analysed and presented in tabular format. The study also employed inferential statistics using multivariate analysis of the general linear model to explore the nexus between independent and dependent variable. Each individual dependent variable indicator (NP and CR) was examined under the variation of arrears.

\subsection{Data Analysis, Results and Discussion}

The information collected was analyzed and presented in Table1. The results for the year 2017 indicated the amount of arrears to have a minimum of Ksh. 57,998, a maximum of Ksh. 43,615,369, a mean of Kshs.5, 087,694 and a standard deviation (SD) of Kshs.7, 520,168.This implied that the average amount of arrears for the 32 Firms was Ksh. 5,087, 694, while the amounts of arrears were spread by Ksh. 7, 520, 168 away from the mean, which explained how different firm arrears largely deviated from each other. The results also indicated Current Ratio (CR) to have a minimum of 0.00, a maximum of 8.49:1, a mean of 2.63:1 and an SD of 2.43:1.This implied that the average firms' CR was 2.63:1, with a deviation of $2.43 \%$ from the mean, $2.43 \%$ was a very small deviation from the mean which simply implied that most of the firms CR tended to approach the mean at a closer range. Most of the firms were operating their CR, slightly above the acceptable industry average CR of 2:1, suggesting that they were in a better liquidity position, slightly higher than the industry average, suggesting that they had outright ability to settle off their short term debts with their current assets. Similarly, results for Net Profit Margin (NP) indicated a minimum represented by a net loss of $1.42 \%$, a maximum of $79.51 \%$, a mean of $18.32 \%$, an SD of $15.9 \%$.The firms' average NP was $18.32 \%$ of the Sales made and an average NP deviation of $15.89 \%$ of their sales. This therefore implied that most of the firms made an average NP of $18.32 \%$ from sales made, which was way above the industry average of $10 \%$, however, most of the firms NP varied greatly from their average mean by $18.32 \%$.The high NP margin suggested that the firms' were better placed to settle off their costs from the revenues received from other accounts receivables not necessary from those who delayed their payments.

\subsection{Amount of Arrears, Class of Arrears, Current Ratio and Net Profit Margin}

Table 1. Descriptive Statistics for Amount of Arrears, Class of Arrears, Current Ratio and Net Profit Margin

Statistics

\begin{tabular}{lll|l|l|l}
\hline & Amount of arrears in millions & Class of arrear & Current Ratio & Net profit margin \\
\hline $\mathrm{N}$ & Valid & 32 & 32 & 32 & 32 \\
\cline { 2 - 6 } & Missing & 0 & 0 & 0 & 0 \\
\hline Mean & 5087694.28 & 2.5625 & 2.630525 & .183150 \\
\hline Std. Deviation & 7520168.359 & 1.47970 & 2.4316922 & .1589724 \\
\hline Minimum & 57998 & 1.00 & .0000 & -.0142 \\
\hline Maximum & 43615369 & 6.00 & 8.4930 & .7951 \\
\hline
\end{tabular}

Source: SPSS Research Data (2019)

We employed multivariate analysis to determine whether there were any differences between independent groups on the two dependent variable indicators. The results are presented in Table 2. 


\subsection{Net Profit and Current Ratio by Classes of Arrears}

Table 2. Multivariate Tests for Net Profit and Current Ratio by Classes of Arrears

Multivariate Tests

\begin{tabular}{|c|c|c|c|c|c|c|c|c|c|}
\hline Effect & & Value & $\mathrm{F}$ & $\begin{array}{l}\text { Hypothesis } \\
\text { d.f }\end{array}$ & Error d.f & Sig. & $\begin{array}{ll}\text { Partial } & \text { Eta } \\
\text { Squared } & \\
\end{array}$ & $\begin{array}{l}\text { Noncent. } \\
\text { Parameter }\end{array}$ & $\begin{array}{l}\text { Observed } \\
\text { Power }\end{array}$ \\
\hline \multirow[t]{4}{*}{ Intercept } & Pillai's Trace & .668 & $25.197^{b}$ & 2.000 & 25.000 & .000 & .668 & 50.394 & 1.000 \\
\hline & Wilks' Lambda & .332 & $25.197^{b}$ & 2.000 & 25.000 & .000 & .668 & 50.394 & 1.000 \\
\hline & Hotelling's Trace & 2.016 & $25.197^{b}$ & 2.000 & 25.000 & .000 & .668 & 50.394 & 1.000 \\
\hline & $\begin{array}{l}\text { Roy's Largest } \\
\text { Root }\end{array}$ & 2.016 & $25.197^{b}$ & 2.000 & 25.000 & .000 & .668 & 50.394 & 1.000 \\
\hline \multirow[t]{4}{*}{ Class } & Pillai's Trace & .387 & 1.248 & 10.000 & 52.000 & .284 & .194 & 12.480 & .571 \\
\hline & Wilks' Lambda & .642 & $1.238^{\mathrm{b}}$ & 10.000 & 50.000 & .291 & .198 & 12.381 & .564 \\
\hline & Hotelling's Trace & .511 & 1.225 & 10.000 & 48.000 & .299 & .203 & 12.254 & .555 \\
\hline & $\begin{array}{l}\text { Roy's Largest } \\
\text { Root }\end{array}$ & .394 & $2.048^{\mathrm{c}}$ & 5.000 & 26.000 & .105 & .283 & 10.239 & .585 \\
\hline
\end{tabular}

Source: SPSS Research Data (2019)

Table2 presents the MANOVA results. The Wilks Lambda criteria revealed no significant difference in means of class of arrears with respect to NP and CR, Wilks lambda $=.642, \mathrm{~F}(10,50)=1.238, \mathrm{p}=.291$. Multivariate partial Eta $=.198$. $\mathrm{P}>0.05$.The significant value of 1.238 was greater than the set alpha value of 0.05 , indicating that they do not contribute to the model as there was no between group dispersion between their means, which implied that there was no statistical significance of either NP or CR when compared on arrears in different classes.

Table 3. Univariate ANOVA Summary Table of Class of Arrear with Net Profit and Current Ratio Tests of Between-Subjects Effects

\begin{tabular}{|c|c|c|c|c|c|c|c|c|c|}
\hline Source & $\begin{array}{l}\text { Dependent } \\
\text { Variable }\end{array}$ & $\begin{array}{lr}\text { Type } & \text { III } \\
\text { Sum } & \text { of } \\
\text { Squares } & \\
\end{array}$ & D.f & $\begin{array}{l}\text { Mean } \\
\text { Square }\end{array}$ & $\mathrm{F}$ & Sig. & $\begin{array}{l}\text { Partial Eta } \\
\text { Squared }\end{array}$ & $\begin{array}{l}\text { Noncent. } \\
\text { Parameter }\end{array}$ & $\begin{array}{l}\text { Observed } \\
\text { Power }\end{array}$ \\
\hline \multirow[t]{2}{*}{$\begin{array}{l}\text { Corrected } \\
\text { Model }\end{array}$} & $\begin{array}{ll}\text { Net } & \text { profit } \\
\text { margin } & \end{array}$ & $.163^{\mathrm{a}}$ & 5 & .033 & 1.361 & .271 & .207 & 6.806 & .402 \\
\hline & Current Ratio & $34.078^{\mathrm{b}}$ & 5 & 6.816 & 1.187 & .342 & .186 & 5.937 & .352 \\
\hline \multirow[t]{2}{*}{ Intercept } & $\begin{array}{l}\text { Net } \\
\text { margin }\end{array}$ & .547 & 1 & .547 & 22.922 & .000 & .469 & 22.922 & .996 \\
\hline & Current Ratio & 146.914 & 1 & 146.914 & 25.597 & .000 & .496 & 25.597 & .998 \\
\hline \multirow[t]{2}{*}{ Class } & $\begin{array}{l}\text { Net } \quad \text { profit } \\
\text { margin }\end{array}$ & .163 & 5 & .033 & 1.361 & .271 & .207 & 6.806 & .402 \\
\hline & Current Ratio & 34.078 & 5 & 6.816 & 1.187 & .342 & .186 & 5.937 & .352 \\
\hline \multirow[t]{2}{*}{ Error } & $\begin{array}{l}\text { Net } \quad \text { profit } \\
\text { margin }\end{array}$ & .621 & 26 & .024 & & & & & \\
\hline & Current Ratio & 149.229 & 26 & 5.740 & & & & & \\
\hline \multirow[t]{2}{*}{ Total } & $\begin{array}{l}\text { Net } \\
\text { margin }\end{array}$ & 1.857 & 32 & & & & & & \\
\hline & Current Ratio & 404.736 & 32 & & & & & & \\
\hline \multirow[t]{2}{*}{$\begin{array}{l}\text { Corrected } \\
\text { Total }\end{array}$} & $\begin{array}{l}\text { Net profit } \\
\text { margin }\end{array}$ & .783 & 31 & & & & & & \\
\hline & Current Ratio & 183.307 & 31 & & & & & & \\
\hline
\end{tabular}

Source: Research Data (2019)

Table 3 revealed one-way UNIANOVA results which indicated that the effects between class of arrears did not significantly vary with NP, F $(5,26)=1.361, p=.271$ since $p>0.05$; Partial Eta squared was .207 , which indicated that $20.7 \%$ of the variance associated with each of the main effects and error was accounted for by the NP, however, not very significant since $p>0.05$. Similarly, the effect between class of arrears did not significantly vary with $C R, F(5,26)$ $=1.187, p=.342$ since $p>0.05$; partial Eta squared was .186 , which indicated that $18.6 \%$ of the variance associated with each of the main effects and error was accounted for by the CR. Suggesting that the percentage variance in individual dependent variable indicators (NP and CR) could not be explained by differences in levels of the independent variable (Payment arrears classes), implying that these effects contributed more to the model. Examination of post hoc 
results revealed in Appendix 1, further revealed that there was no statistical difference between class of arrears and NP and between class of arrears and CR.

The effects between Class of arrears did not significantly affect NP since F $(1.361)=.271$ since $p>0.05$, similarly, effects between class of arrears did not significantly affect CR since $F(1.187)=.342$ since $p>0.05$. Suggesting that the percent variance in individual dependent variable indicators (NP and CR) could not be explained by differences in levels of the independent variable (Payment arrears classes), implying that these effects contributed more to the model.

\subsection{Effects between Amount of arrears and Net Profit}

Table 4. Tests of Between-Subjects Effects between Amount of arrears and Net Profit

Tests of Between-Subjects Effects

\begin{tabular}{|c|c|c|c|c|c|c|}
\hline Dependent Variable: & Net profit margin & & & & & \\
\hline Source & $\begin{array}{l}\text { Type III Sum of } \\
\text { Squares }\end{array}$ & D.f & Mean Square & $\mathrm{F}$ & Sig. & Partial Eta Squared \\
\hline Corrected Model & $.004^{\mathrm{a}}$ & 1 & .004 & .166 & .687 & .006 \\
\hline Intercept & .794 & 1 & .794 & 30.569 & .000 & .505 \\
\hline Amount & .004 & 1 & .004 & .166 & .687 & .006 \\
\hline Error & .779 & 30 & .026 & & & \\
\hline Total & 1.857 & 32 & & & & \\
\hline Corrected Total & .783 & 31 & & & & \\
\hline
\end{tabular}

Source: Research Data (2019)

As shown in table 4, tests of between-subjects effects of Unit Anova of the General Linear Model between independent variable (Amount of Payment arrears) and the NP indicated a partial Eta squared of 6\% with an adjusted partial Eta squared of $-2.8 \%$. This implied that amount of payment arrears in the model explains a .6\% change in NP which is not statistically significant, while the other $99.4 \%$ change could be explained better by other variables if they could have been fitted in the model. As shown in table 4.4, the tests of between subject effects analyzed data was used to generate inferences, which indicated $\mathrm{F}$ statistics, $\mathrm{F}(1,30)=.166, \mathrm{p}=.687$,implying that the main small effect sizes of payment arrears was not statistically significant, since p>0.05. (According to Richardson, 2011), small effect sizes range from .0099 and below).

Table 5. Parameter Estimates of Arrears and Net Profit

Parameter Estimates

\begin{tabular}{|c|c|c|c|c|c|c|c|c|}
\hline \multicolumn{9}{|c|}{ Dependent Variable: $\quad$ Net profit margin } \\
\hline Parameter & B & Std. Error & $\mathrm{T}$ & Sig. & \multicolumn{2}{|c|}{ 95\% Confidence Interval } & \multicolumn{2}{|l|}{$\begin{array}{l}\text { Partial } \\
\text { Squared }\end{array}$} \\
\hline Intercept & .191 & .035 & 5.529 & $\frac{0}{000}$ & 121 & $\frac{\text { poper Doundu }}{262}$ & 505 & \\
\hline Amount & $-1.569 \mathrm{E}-9$ & 3.849E-9 & -.408 & 687 & $-9.429 \mathrm{E}-9$ & $6.292 \mathrm{E}-9$ & .006 & \\
\hline
\end{tabular}

Source: Research Data (2019)

Table 5 indicates an intercept value when the NP was set to 0.Thus the intercept was equivalent to the mean NP. The NP coefficient was the predicted increase in NP for a unit increase in arrears. Since the amount of arrears value of 1 was those amounts of arrears, this coefficient represented the change in the estimated NP for those construction firms compared to those without payment arrears. $-1.569 \mathrm{E}-9$ value was the difference between the two means, suggesting that adding it to the constant provided the mean of arrears. Taking the total population of construction firms, significance level was not of vital importance however if by chance the conceptualization of the current situation could have prevailed as though it was from sampling of hypothetical population, the p-value of .687 would indicate that very lower likelihood that the coefficient was likely to result from the probability of choosing the random samples from the hypothetical populations with same means. $\mathrm{P}$ value of parameter estimates is similar to those of $\mathrm{F}$ test of between subject test of amount of arrears and NP. The $\mathrm{F}$ value was the square of the $\mathrm{Z}$ value. The standard error of .035 represented the difference between the population mean and the sample mean which was very small. it implied the estimated standard deviations of residuals, which suggested that approximate .035 were predicted errors for residuals, which was very small, implying that the predictions were accurate as possible. The lower bound was .121 whereas the upper bound was .262.This was derived by taking into account the mean of the sample population which was a point estimate of the mean of the entire population, which ideally could not be the same as the entire population mean, hence requiring an interval estimate to approximate the population mean, which was a given amount either added or 
subtracted from the sample mean, creating a margin of error in order to obtain a lower and an upper bound for the interval estimate, hence a confidence interval for the entire population mean, which therefore suggested that we were confident that the mean of the entire population was between the lower and upper bounds of the confidence interval.

\subsection{Effect of Amount of Arrears on Current Ratio}

Table 6. Tests of Between-Subjects Effects between Amount of Arrears and Current Ratio

Tests of Between-Subjects Effects

\begin{tabular}{ll|l|l|l|l|l}
\hline Dependent Variable: & $\begin{array}{l}\text { Current Ratio } \\
\text { Type III Sum of }\end{array}$ & D.f & Mean Square & F & Sig. & $\begin{array}{l}\text { Partial } \\
\text { Squared }\end{array}$ \\
Squares & Square & D.f & Eta \\
\hline Corrected Model & $6.837^{\mathrm{a}}$ & 1 & 6.837 & 1.162 & .290 & .037 \\
\hline Intercept & 188.898 & 1 & 188.898 & 32.113 & .000 & .517 \\
\hline Amount & 6.837 & 1 & 6.837 & 1.162 & .290 & .037 \\
\hline Error & 176.470 & 30 & 5.882 & & & \\
\hline Total & 404.736 & 32 & & & & \\
\hline Corrected Total & 183.307 & 31 & & & & \\
\hline
\end{tabular}

As shown in table 6 tests of between-subjects effects of the General Linear Model between independent variable (Amount of Payment arrears) and the CR indicated a partial Eta squared of 3.7\% with an adjusted partial Eta squared of 0.5\%.This implied that amount of payment arrears in the model explained a $3.7 \%$ change in CR, while the other $96.3 \%$ change could be explained better by other variables when fitted in the model. As further shown in table 6 of the General Linear Model, analyzed data was used to generate inferences, indicating F statistics, $\mathrm{F}(1,30)=1.162, \mathrm{p}=.29$, implying that the medium effect sizes of payment arrears were not statistically significant, since $p>0.05$. (According to Richardson, 2011), medium effect sizes range above .0099 and below .0588).

Table 7. Parameter Estimates of Arrears and Current Ratio

Parameter Estimates

\begin{tabular}{|c|c|c|c|c|c|c|c|c|}
\hline \multicolumn{2}{|c|}{ Dependent Variable: } & \multicolumn{3}{|c|}{ Current Ratio } & & \multirow[b]{2}{*}{$\begin{array}{l}\text { Partial } \\
\text { Squared }\end{array}$} & \multirow[b]{2}{*}{ Eta } \\
\hline Parameter & B & Std. Error & $\mathrm{T}$ & Sig. & & $\begin{array}{l}\text { Interval } \\
\text { Upper Bound }\end{array}$ & & \\
\hline Intercept & 2.948 & .520 & 5.667 & .000 & 1.886 & 4.011 & .517 & \\
\hline Amount & $-6.245 \mathrm{E}-8$ & $5.793 \mathrm{E}-8$ & -1.078 & 290 & $-1.807 \mathrm{E}-7$ & $5.585 \mathrm{E}-8$ & .037 & \\
\hline
\end{tabular}

Source: SPSS Research Data (2019)

Table 7 indicates an intercept value when the $\mathrm{CR}$ was set to 0.Thus the intercept was equivalent to the mean CR. The CR coefficient was the predicted increase in CR for a unit increase in arrears. Since the Amount of arrears value of 1 was those amounts of arrears, this coefficient represented the change in the estimated CR for those construction firms compared to those without payment arrears. $-6.245 \mathrm{E}-8$ value was the difference between the two means, suggesting that adding it to the constant provided the mean of arrears. Taking the total population of construction firms, significance level was not of vital importance however if by chance the conceptualization of the current situation could have prevailed as though it was from sampling of hypothetical population, the p-value of .290 would indicate that very lower likelihood that the coefficient was likely to result from the probability of choosing the random samples from the hypothetical populations with same means. $\mathrm{P}$ value of parameter estimates is similar to those of $\mathrm{F}$ test of between subject test of amount of arrears and CR. The $\mathrm{F}$ value was the square of the $\mathrm{Z}$ value. The standard error of 5.793E-8 represented the difference between the population mean and the sample mean which was very small. it implied the estimated standard deviations of residuals, which suggested that approximate 5.793E-8 were predicted errors for residuals, which was very small, implying that the predictions were accurate as possible. The lower bound was 1.186whereas the upper bound was .4.011. This was derived by taking into account the sample mean which was a point estimate of the population mean, which ideally could not be the same as the population mean, hence requiring an interval estimate to approximate the population mean, which was a given amount either added or subtracted from the sample mean, creating a margin of error in order to obtain either a lower and an upper bound for the interval estimate, hence a confidence interval for the population mean, which therefore suggested that we were confident that the population mean was between the lower and upper bounds of the confidence interval. 


\section{Discussions}

Results from descriptive statistics clearly revealed that the construction firms Mean NP and mean CR were way above the industry average, which suggested that as far as the firms had payment arrears, their financial performance still levelised, which implied that payment delays had no significant effect on either NP or CR. Similarly, results from multivariate analysis indicated no statistical significant effects between payment arrears and financial performance. These findings are inconsistent with Achode and Rotich (2016) who found out that an increase in accounts payables as trade credit enhanced performance of companies through increased profitability. In the same vein, this study finding is inconsistent with Flynn and Pessoa (2014) and Diamond and Schiller (1993) who found out that prolonged delays in public payments negatively affects private sector liquidity and profits and in the long run growth gets affected. Nonetheless, this findings are in tandem with Checherita.et al (2015)who found out that paying a bill only moved liquidity across firms, but did not affect combined private sector liquidity implying that whether payment arrears are made or not, there exists no effect between payments and liquidity. These study findings are also in tandem with Nwakaego and Ikechukwu (2016) who also revealed that there was no effect of accounts payables on profitability. Similarly, this study finding coincide with Cramer (1972) who posited that delayed payment issues usually become problematic to handle as there was no straightforward statistics on the effect of payment delays on economic performance of a firm. Maybe other measures could have given different results, since according to Carton and Hofer (2010) they were of the opinion that there was no concurrence concerning the best or even subtle measures of financial performance, as there have been no existing study that had successfully proposed and empirically tested a generalizable multidimensional model of organizational financial performance constructs and their appropriate measures. Similarly, as far as the results indicate to effect, probably in the long run of delayed payments, the effects might appear more significant, as it also becomes very difficult to detect whether firms are under financial distress, since according to Outecheva, (2007) who supposed that the most trickiest bit about financial distress is to detect unfavourable processes beforehand so as to gain more time for response. Similarly, the effect of overpricing to cover for premiums on interest expenses according to Diamond and Schiller (1993) could have probably created effects which cancelled each other, since the action of overpricing to earn more income, cancelled the effect of increased expenses such as interest expenses. Which basically indicated that no effect existed between payment delays and Financial Performance? These study findings were therefore in tandem with Nwakaego and Ikechukwu (2016) who posited that an increase in accounts payable did not have any influence on profitability. The study findings concurred with Checherita.et al (2015) who found out that paying a bill only moved liquidity across firms, but did not affect composite private sector liquidity implying that whether payment arrears are made or not, there exists no effect between payments and liquidity, probably there existed other factors such as management styles and strategies which could have affected the variables.

\section{Conclusion, Recommendations and Limitations}

We sought to determine whether payment delays affected financial performance of construction firms in Vihiga County. The objective was successfully achieved by obtaining data from the year 2017 audited financial statements of the 32 individual construction firms. From the study findings, Descriptive statistics revealed that there was no effect between payment arrears on either NP or CR. similarly, inferential statistics using Multivariate Tests for NP and CR with classes of arrears revealed that there was no statistical significant difference between means of Payment Arrears with NP and CR. Similarly, Univariate ANOVA analysis revealed that there exist no statistical significant differences between classes of arrears with NP and CR under separate cases. Whereas Tests of Between-Subjects Effects between Amount of arrears with NP and CR indicated no effects between those variables.

The findings further revealed that there was no effect between payment delays and financial performance. Payment delays therefore does not affect NP or CR as there is no statistical significant association between them, this study findings are in line with Cramer (1972) who alluded to the fact that delayed payment issues usually become problematic to handle as there was no straightforward statistics on the effect of payment delays on economic performance of a firm. Our conclusion however, is that late payments in commercial transactions by the public organizations and private entities have detrimental effects on the business environment, especially by exacerbating the burden of already financially constrained firms which can ultimately push them out of business.

The study findings are highly recommended to contribute to the formation of a new theory that will explain which factor significantly affects financial performance, since payment delays do not affect performance, maybe other factors such as management style and strategies could have affected financial performance, or alternatively, maybe other sufficient financial performance measures which the researcher was not aware of could have been employed to test whether a relationship existed, as carton and Hofer (1972), still doubts if the subtle measures ever existed. The study findings further recommends that maybe in the long run a relationship might be testable and generalizable by using longitudinal studies. The study findings should enable the financial managers to formulate and implement sound 
financial management to assess factors which are more likely to affect their financial performance as well as consider how payment delays affect other business operations and performance.

The researchers' data was restricted to those construction firms whose financial statements had been duly audited and were NCA registered. The researcher was limited to only 32 construction firms and omitted eight (8) firms' data since they had significant outliers which could have influenced the end results of the study. The researcher was also limited to only 2 classes of ratios, profitability and liquidity as measures of financial performance. In regard to this study finding, the researcher recommends that a further research be done longitudinally so as to assess the effect of payment delays and financial performance. The researcher recommends that another study be conducted on the effect of payment delays on financial performance using leverage and efficiency ratios as indicators of financial performance. Further to that, the researcher recommends that similar research be carried out in different industries so as to have a better generalization.

\section{References}

Abdul-Rahman, H. (2009). Financial related causes contributing to project delays. Journal of Retail \& Leisure Property, 8(3), 225-238. https://doi.org/10.1057/rlp.2009.11

Achode, B., \& Rotich, G. (2016). Effects of Accounts Payables as a Source of Financing onPerformance of Listed Manufacturing Firms at the Nairobi Securities Exchange. International Journal of Research Studies in Agricultural Sciences, 2(4), 24-32. https://doi.org/10.20431/2454-6224.0204003

Aibunu, A. A., \&Jagboro, G. O. (2002). The Effects of Construction Delays on Project Delivery in Nigerian Construction Effects Industry. International Journal of Project Management, 20, 593-599. https://doi.org/10.1016/S0263-7863(02)00028-5

Akali, T. \& Sakaja, Y. (2018). Influence of Contractors' Financial Capacity on Performance of Road Construction in Kakamega County-American Scientific Research Journal for Engineering, Technology, and Sciences, 46(1).

Akisinku, E. O., \& Ajayi, M. O. (2016). Effects of Delayed Payment of Contractors on Construction Project Delivery in Nigeria. Paper Presented on 20-22 September 2016 at The Construction, building and Real Estate Research Conference of the Royal Institution of Chartered Surveyors in Toronto, Canada.

Assaf, S. A., \& Al-Hejji, S. (2006). Causes of Delayed Payment in Large Construction Projects. International Journal of Project Management and Economics, 16, 327-337.

Auditor General. (2019). Special Report on Pending Bills of the County Government of Vihiga.

Baharin, I., \&Sentosa, I. (2013). Capital structure and the post performance Factors of MalaysianPN 17 Firms. International Journal of Current Business and Social sciences, 1(2), 58-80.

Bhunia, A., Mukhuti, S. S., \& Roy, S. G. (2011). Financial Performance Analysis-A Case Study. Research Journal of Social Sciences, 3(3), 269-275. https://doi.org/10.5296/jmr.v3i2.574

Campbell, J., Hilscher, J., Szilagyi, J. (2006). In Search of Distress Risk. WorkingPaper 12362, NBER series. https://doi.org/10.3386/w12362

Ceric, A. (2012). Communication risk in Construction projects: Application of Principal-Agent theory. International Journal of Organization Management and Technology, 4(2), 522-533. https://doi.org/10.5592/otmcj.2012.2.8

Checherita, C., Klemm, A., \& Viefers, P. (2015). Governments' Payment Discipline: The Macroeconomic Impact of Public Payment Delays and Arrears. Working Paper, 15(13). https://doi.org/10.5089/9781484317020.001

Connell. Economic Impact of Late Payments. European Commission. (2014). Market reforms at work in Italy, Spain, Portugal and Greece. European Economy.

Cramer, J. (1972). Incompatibility of Bad Debt Expense with Contemporary Accounting Theory. The Accounting Review, 47(3), 596-598.

Diamond, J., \& Schiller, C. (1993). Government Arrears in Fiscal Adjustment programs. How to measure the fiscal deficit, (International Monetary Fund), 115-143.

Eisenhardt, M. K. (1989). Agency Theory: An Assessment and Review. The Academy of Management Review, 14(1), 57-74. https://doi.org/10.5465/amr.1989.4279003

Flynn, S., \& Pessoa, M. (2014). Prevention and Management of Government Expenditure and Arrears. IMF Technical Notes and Manual, 14(01). https://doi.org/10.5089/9781498313650.005

Halim, M., Haniff, S., Junoh. M., \& Osman, A. (2014). Financial performance and the management Issues of Bumiputera Construction firms in the Malaysian Construction Industry. Journal of Scientific Research \& Reports, 3(9), 1190-1202. https://doi.org/10.9734/JSRR/2014/8418 
Hamid, A. A., Zakaria, R., Mohd Badroldin, K. M., Abdul Raman, S., \&Mohandes, R. S. (2016). Late Payment Practices in the Malaysian Construction Industry. Malaysian construction. Journal of Civil Engineering, 28(3), $149-162$.

Hasmori, M. F., Ismail. \& Said, I. (2012). Issues of Late and Non Payment Among Contractors in Malaysia, $3^{\text {rd }}$ International Conference on Business and Economic Research Proceeding, 12-13 March 2012, Golden Flower Hotel, Bandung, Indonesia.

Jensen, M., \& Meckling, H. (1976). Theory of the Firm: Managerial Behaviour, Agency costs and Ownership Structure. Journal of Financial Economics, 3(4), 305-360. https://doi.org/10.1016/0304-405X(76)90026-X

Jiang, J. (2010). Perspective based on Comprehensive Research on the Management of Project Quality. International Conference on Logistics Systems and Intelligent Management, 9-10 January, 2010, Harbin, China.

Kalckreuth, V. (2005). A wreckers Theory of Financial Distress. Discussion paper Economic studies, Deutsche Bundesbank. Series 1(40).

Kenya Economic Update. (2017). Poised To Bounce Back? Reviving Private Sector Credit Growth and Boosting Revenue Mobilization to Support Fiscal Consolidation. World Bank Group. Edition (16).

Kothari, C. R. (2004). Research Methodology; Method and techniques (2nd ed.). New Delhi, India: New age international Publishers, Ltd.

Kwame, B. A. (2011). The Effect of Delayed payment on Cash flow forecasting of Ghanaian Road Contractors. Unpublished M.Sc Thesis submitted to the Institute of Distance Learning, Kwame Nkrumah University of Science and Technology.

Lip, E. (2003). Construction payment blues-Why that domino effect? Davis Langdon and Seah Consultancy: Executive Summaries for the Practitioner, 3, 1-4.

Mansfield, N. R., Ugwu, O. O., \& Doran, T. (1994). Causes of Delay and Cost Overruns in Nigerian Construction Projects. International Journal of Project Management, 12(4), 254-260. https://doi.org/10.1016/0263-7863(94)90050-7

Mezher, T., \& Tawil, W. (1998).Causes of Delays in the Construction Industry in Lebanon. Engineering, Construction and Architectural Management, 5(3), 252-260. https://doi.org/10.1108/eb021079

Miad, S. L., \& Smith, C. W. (1992). Accounts Receivable Management Policy: Theory and Evidence. The Journal of Finance, 47(1), 169-200. https://doi.org/10.1111/j.1540-6261.1992.tb03982.x

Miller, T., \& Wongsaroj. S. (2017). The Domino Effect: The Impact of Late Payments-A study for Sage, Plum Consulting.

Muna, A. (2015).Comparative Financial Performance Analysis. A Study on Selected Cement Companies in Bangladesh. Bangladesh University.

Mwangi, M. J. (2016). Factors Influencing Performance of Contractors in the Road Construction Sector: A Case of Selected Contractors in Kenya. Journal of Construction Project Management and Innovation, 15(3), 6-17.

Nasser, A. (2013). The Effect of Payment Delay on Construction Projects in Gaza Strip.

Nwakaego, D. A., \& Ikechukwu, O. (2016). Management of Accounts Payable on the Financial Performance of Industrial/Domestic Manufacturing Companies in Nigeria.IOSR Journal of Humanities and Social Science, 21(7), 54-61. https://doi.org/10.9790/0837-2107065461

Obodoh. D. A., \& Obodoh. C. (2016). Causes and Effects of Construction Project Delays in Nigerian Construction Industry.International Journal of Innovative Science, Engineering and Technology, 5(3), 65-84.

Odenigbo, O. G. (2018). Causes and Effects of Delayed Payment on Construction Project Delivery. Unpublished Master's Thesis Submitted to University of Lagos Akoka, Yaba Nigeria.

Okeyo, P. M., Rambo, M. C., \& Odundo, A. P. (2015). Effects of Delayed Payment of Contractors on the Completion of Infrastructural Projects: A Case of Sondu-Miriu Hydropower Project, Kisumu County, Kenya. Chinese business Review, 14(7), 325-336. https://doi.org/10.17265/1537-1506/2015.07.001

Richardson, J. T. E. (2011). Eta Squared and Partial eta squared as measurements of Effect size in educational Research .Education Research Review: 135-147. https://doi.org/10.1016/j.edurev.2010.12.001

Seboru, M. A. (2015). An Investigation into Factors Causing Delays in Road Construction Projects in Kenya. American Journal of Civil Engineering, 3(3), 51-63. https://doi.org/10.11648/j.ajce.20150303.11

Vihiga County Fiscal Strategy Paper 2019.

Woldesenebt, T. T. (2011). Comparative Studies on Financial Performance of Commercial banks in Ethiopia. Problems 
and Prospects. Unpublished Master's Thesis, Ankara Yildrim Beyazit University, Ethiopia.

Wuni, Y., Boafo, H., \& Kumi, S. (2017). Critical Causes and Effects of Payment Delays in the Execution of Public Construction Projects in Ghana: Fresh Evidence from the Brong- Ahafo Region.

\section{Copyrights}

Copyright for this article is retained by the author(s), with first publication rights granted to the journal.

This is an open-access article distributed under the terms and conditions of the Creative Commons Attribution license which permits unrestricted use, distribution, and reproduction in any medium, provided the original work is properly cited. 